\title{
Corrosion in Tap Water and Hot Water Supply Facilities of Stainless Steel Type 304 Pipes
}

\author{
Noriyuki Tanaka1,2*, Shigeru Sato' ${ }^{1}$, Ippei Watanabe², Yutaka Yamada ${ }^{2}$, Osamu Sakurada ${ }^{2}$ \\ ${ }^{1}$ Technical Research Laboratory, DAI-DAN Co., Ltd., Saitama, Japan \\ ${ }^{2}$ Gifu University, Gifu, Japan \\ Email: `tanakanoriyuki@daidan.co.jp, satoshigeru@daidan.co.jp,w4524080@edu.gifu-u.ac.jp,y.yamada@daiwatec.com, \\ sakurada@gifu-u.ac.jp
}

How to cite this paper: Tanaka, N., Sato, S., Watanabe, I., Yamada, Y. and Sakurada, O. (2018) Corrosion in Tap Water and Hot Water Supply Facilities of Stainless Steel Type 304 Pipes. Materials Sciences and Applications, 9, 68-80.

https://doi.org/10.4236/msa.2018.91005

Received: November 8, 2017

Accepted: January 7, 2018

Published: January 10, 2018

Copyright $\odot 2018$ by authors and Scientific Research Publishing Inc. This work is licensed under the Creative Commons Attribution International License (CC BY 4.0).

http://creativecommons.org/licenses/by/4.0/

\begin{abstract}
We performed corrosion case study and corrosion tests to assess the corrosion resistance of stainless steel type 304 pipes in tap water and hot water facilities. Circulating test equipment used for corrosion tests and two types of sample, plates and straight pipe specimens, were examined under different conditions of residual chlorine concentration in the test water. The results of case study analysis indicated that high degrees of pitting corrosion occurred on straight pipes with inner diameter $<50 \mathrm{~mm}$. The results of corrosion tests showed that the residual chlorine concentration around the pitting corrosion of stainless steel type 304 was greater than $0.3 \mathrm{mg} / \mathrm{L}$ in the plate, regardless of the remaining chlorine concentration in the straight pipe specimens. These results suggest that straight pipes have higher corrosion susceptibility because of bending during production.
\end{abstract}

\section{Keywords}

Stainless Steel, Corrosion Resistance, Tap water, Residual Chlorine, Corrosion Potential

\section{Introduction}

Due to their superior corrosion resistance, stainless steel type 304 pipe began to be used in building facilities from the early 1980s, and the demand for use in water and hot water supply facilities has since increased several fold. However, the increased demand was accompanied by many problems associated with corrosion. Many reports in the 1990s presented examples of stress corrosion cracking (SCC) of stainless steel type 304 used as hot water pipes [1] and corrosion resistant of the weld [2]-[10], a thing about is a representative memoir. 
Since the early 2000s, however, there have been increasing reports of pitting corrosion in straight stainless steel pipes [11] [12] [13] [14]. This corrosion was suggested to be due to residual chlorine, produced from sodium hypochlorite used as a disinfectant in water treatment plants. The corrosion study that paid its attention to the straight pipe (non-weld) is a report about SCC until now. For example, it is a report "Effects of $\mathrm{P}$ and $\mathrm{Cu}$ on SCC Resistance of Austenitic Stainless Steel in Dilute $\mathrm{NaCl}$ Solution" [15]. There have been few studies regarding pitting corrosion of straight pipes in tap water environments.

This study was performed to investigate the factors involved in pitting corrosion of straight pipes. Here, we report the results of corrosion testing under conditions simulating the actual tap water environment to obtain basic knowledge regarding the effects of tap water on stainless steel pipes. We used plate specimens and straight pipes as test materials in this study.

\section{Corrosion Case Study}

\subsection{Method}

We investigated 18 cases [16] in the company and 10 cases [11] [12] [13] [14] of stainless steel type 304 reported during the 16-years period from 2000 through 2015 ( 28 cases in total). All 28 buildings have water supply and hot water supply facilities. A Study was classified the corrosion behavior, the occurrence part (a straight pipe and others) and the in inside diameter (more than $50 \mathrm{~mm}$ or less and $60 \mathrm{~mm}$ ). Residual chlorine concentration was classified as $<0.4 \mathrm{mg} / \mathrm{L}$ or $>0.4$ $\mathrm{mg} / \mathrm{L}$, as the mean residual chlorine concentration in Japan lies within the range of $0.3-0.4 \mathrm{mg} / \mathrm{L}$ according to water service quality data.

\subsection{Result and Discussion}

Figure 1(a) shows classified facilities use. About facilities use, 21 of 28 corrosion cases were the cases of hot water supply facilities, and there was much number of occurrence parts of the pitting corrosion water supply and hot water supply facilities together. Figure 1(b) shows the parts with corrosion. About occurrence part, 21 cases were the cases of the straight pipe, and there was much occurrence number of pitting corrosion with 14 . Figure 1 (c) shows classified inside diameter. With the hot water supply facilities, there were many occurrence cases less than $50 \mathrm{~mm}$. With one water supply facilities did not understand the clear tendency for a lot of ignorance in study case. In addition, it is thought that cases less than $50 \mathrm{~mm}$ inside diameter were often found because corrosion produced less than $50 \mathrm{~mm}$ in the system even an case which it classified more than $60 \mathrm{~mm}$. Figure 1(d) shows residual chlorine concentrations. It was the use environment where about half was within $0.4 \mathrm{mg} / \mathrm{L}$ with the hot water supply facilities and about half of the case more than $0.4 \mathrm{mg} / \mathrm{L}$ with the water supply facilities.

As a result of having investigated 28 corrosion cases, there were many ratios of pitting corrosion of straight pipe with less than $50 \mathrm{~mm}$ inner diameter in the water supply and hot water supply facilities together. $50 \mathrm{~mm}$ inner diameter or 


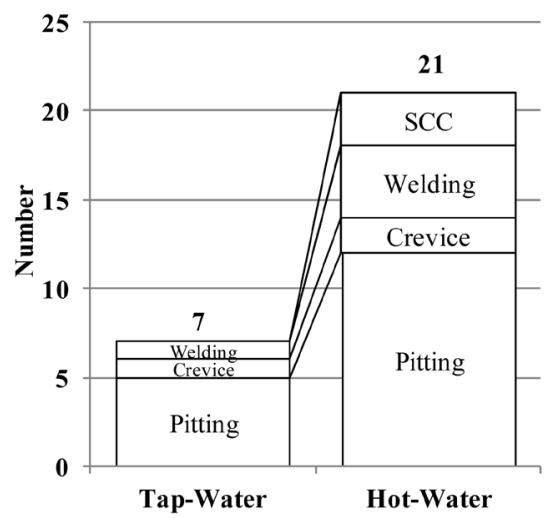

(a)

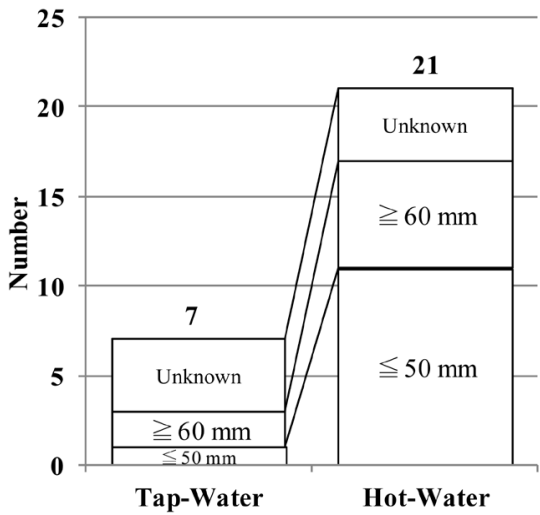

(c)

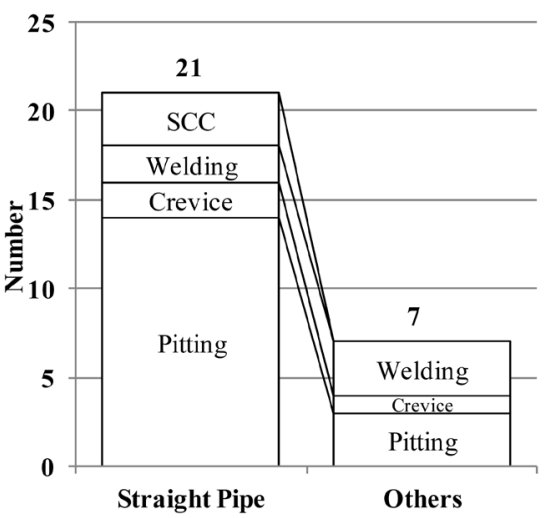

(b)

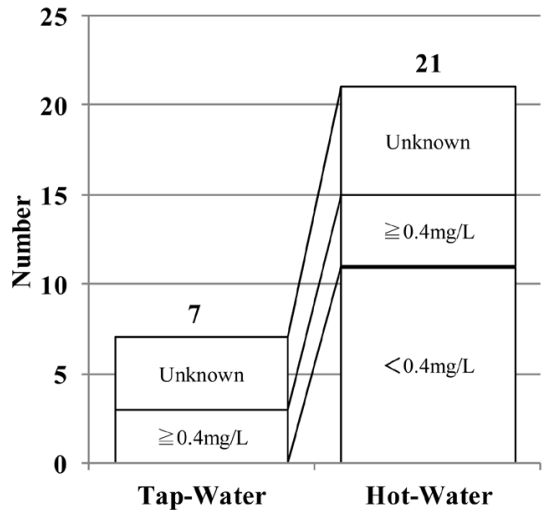

(d)

Figure 1. Comparison of (a) tap water and hot water facilities; (b) corrosion position; (c) inner diameter of pipe and (d) residual chlorine concentration by research of corrosion in tap water and hot water supply facilities used stainless steel type 304 pipes [11] [12] [13] [14] [16].

less may be pipe causes to be used as a branch pipe and a hot water pipe of the hot water supply pipe, and there is much consumption. In addition, as the inner diameter became small with $13 \mathrm{~mm}$ from $50 \mathrm{~mm}$ increased the consumption, and in fact it was expected to be larger than the number of this study.

Deformation-induced martensite is produced by cold work in stainless steel type 304. This deformation-induced martensite increases general corrosion amount in the active region as compared with austenite stainless steel type 304, and pitting corrosion occurs [17]-[24]. Straight pipe is produced by welding after bending of the raw plate material. Therefore, as the radius of curvature became small with decreasing inside diameter, the production of deformation-induced martensite increased due to severe bending. The large number of corrosion cases in pipes $<50 \mathrm{~mm}$ in inside diameter may have been due to the effect of deformation-induced martensite on corrosion resistance [20] [21].

Furthermore, water temperature and residual chlorine concentration were suggested to influence corrosion resistance. The reason occurs with the water supply having high concentration and occurs even if concentration is low with the hot water supply facilities. 


\section{Study of Influence on Corrosion Resistant by Inner Diameter and Residual Chlorine}

Corrosion tests were performed with addition of sodium hypochlorite to the test water to simulate residual chlorine in the tap water actual environment. Here, we refer to the sodium hypochlorite concentration in test water as the residual chlorine concentration.

\subsection{Method}

\subsubsection{Test Materials}

The test materials consisted of stainless steel type 304 produced from cold-rolled stainless steel plate sheet ("JIS G 4305 , hereafter referred to as plate") $50 \mathrm{~mm}$ in length $\times 30 \mathrm{~mm}$ in width $\times 0.8 \mathrm{~mm}$ wall thickness, and stainless steel type 304 of light gauge stainless steel tubes for ordinary piping ("JIS G 3448 , hereafter referred to as straight pipe") $13 \mathrm{~mm}$ in inner diameter $\times 15.88 \mathrm{~mm}$ in outside diameter $\times 0.8 \mathrm{~mm}$ wall thickness $\times 150 \mathrm{~mm}$ in length. Table 1 shows the chemical compositions of the specimens used. The test materials were obtained from commercial sources. All test materials were subjected to degreasing only without surface scrubbing prior to use in the experiments. In addition, the straight pipe specimens worked to coat only the outside, and the plate specimens left a $1 \mathrm{~cm}^{2}$ corner as an effective area and coating processed the whole.

\subsubsection{Circulating Corrosion Test Equipment}

Figure 2 shows a schematic drawing of the circulating corrosion test equipment used in this study. The equipment consisted of a 10-L test water preparation tank, 1-L test beaker, the circulation piping during a preparation tank and the test beaker, residual chlorine concentration control unit, circulation piping during chlorine concentration control unit and a preparation tank and a carbon dioxide supply device. Test water was passed through the circulation corrosion test equipment using a circulation pump. The plate specimens were installed in the test beaker, while the straight pipe specimens were installed between the circulation pump of test beaker exit side and preparation tanks.

\subsubsection{Corrosion Test Condition}

Table 2 shows corrosion test condition. Table 3 shows chemical analysis of raw water for test water. The test water prepared residual chlorine concentration to $0.0,0.3,0.4,0.5$ and $1.0 \mathrm{mg} / \mathrm{L}$ and circulated. The test water was exchanged $3 \mathrm{~L} / 3$

Table 1. Chemical composition of the specimens used. [wt\%]

\begin{tabular}{ccccccccccc}
\hline Specimen & $\mathbf{C}$ & $\mathrm{Si}$ & $\mathrm{Mn}$ & $\mathbf{P}$ & $\mathrm{S}$ & $\mathrm{Ni}$ & $\mathrm{Cr}$ & $\mathrm{Mo}$ & $\mathrm{Cu}$ & $\mathrm{N}$ \\
\hline Plate & 0.057 & 0.34 & 1.06 & 0.032 & 0.004 & 8.09 & 18.07 & 0.15 & 0.36 & 0.035 \\
Pipe 13 mm & 0.036 & 0.37 & 1.05 & 0.033 & 0.005 & 8.07 & 18.22 & 0.14 & 0.31 & 0.039 \\
Pipe 25 mm & 0.051 & 0.46 & 1.04 & 0.032 & 0.002 & 8.06 & 18.28 & 0.12 & 0.31 & 0.036 \\
Pipe 50 mm & 0.043 & 0.39 & 1.04 & 0.029 & 0.002 & 8.05 & 18.02 & 0.07 & 0.21 & 0.041 \\
\hline
\end{tabular}


Table 2. Corrosion test condition.

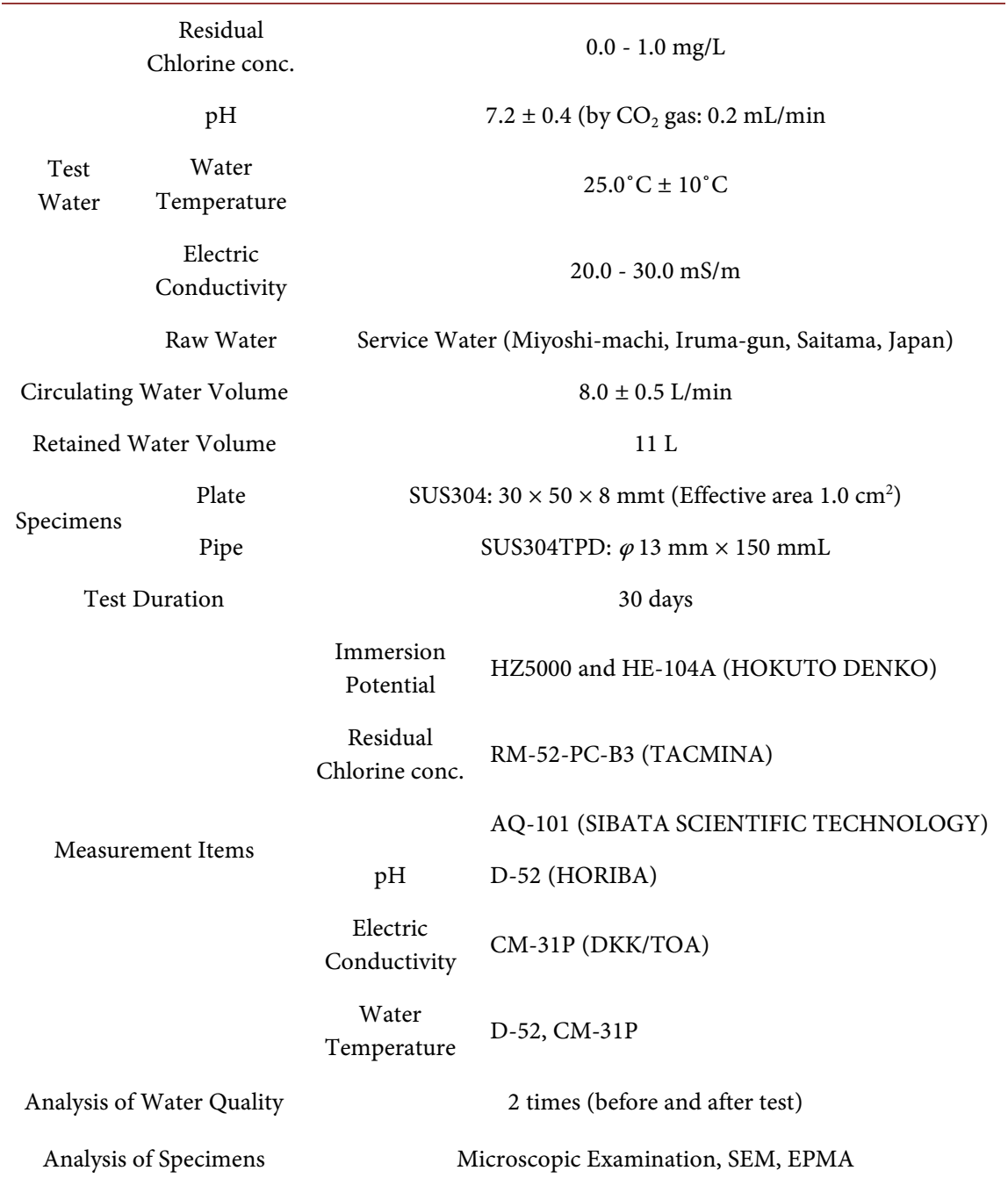

Table 3. Chemical analysis of test water.

\begin{tabular}{|c|c|c|}
\hline \multicolumn{2}{|c|}{ Quality of Water Item } & \multirow{2}{*}{$\begin{array}{c}\text { Results } \\
7.6\end{array}$} \\
\hline $\mathrm{pH}$ & {$[-]$} & \\
\hline Electric Conductivity & {$[\mathrm{mS} / \mathrm{m}]$} & 21.9 \\
\hline Acid Consumption (pH 4.8) & {$\left[\mathrm{mgCaCO}_{3} / \mathrm{L}\right]$} & 51 \\
\hline $\mathrm{Cl}^{-}$ & {$[\mathrm{mg} / \mathrm{L}]$} & 16 \\
\hline $\mathrm{SO}_{4}^{2-}$ & {$[\mathrm{mg} / \mathrm{L}]$} & 23 \\
\hline Total Hardness & {$\left[\mathrm{mgCaCO}_{3} / \mathrm{L}\right]$} & 77 \\
\hline Calcium Hardness & {$\left[\mathrm{mgCaCO}_{3} / \mathrm{L}\right]$} & 56 \\
\hline $\mathrm{SiO}_{2}$ & {$[\mathrm{mg} / \mathrm{L}]$} & 25 \\
\hline $\mathrm{Fe}$ & {$[\mathrm{mg} / \mathrm{L}]$} & $<0.1$ \\
\hline $\mathrm{Cu}$ & {$[\mathrm{mg} / \mathrm{L}]$} & $<0.1$ \\
\hline
\end{tabular}




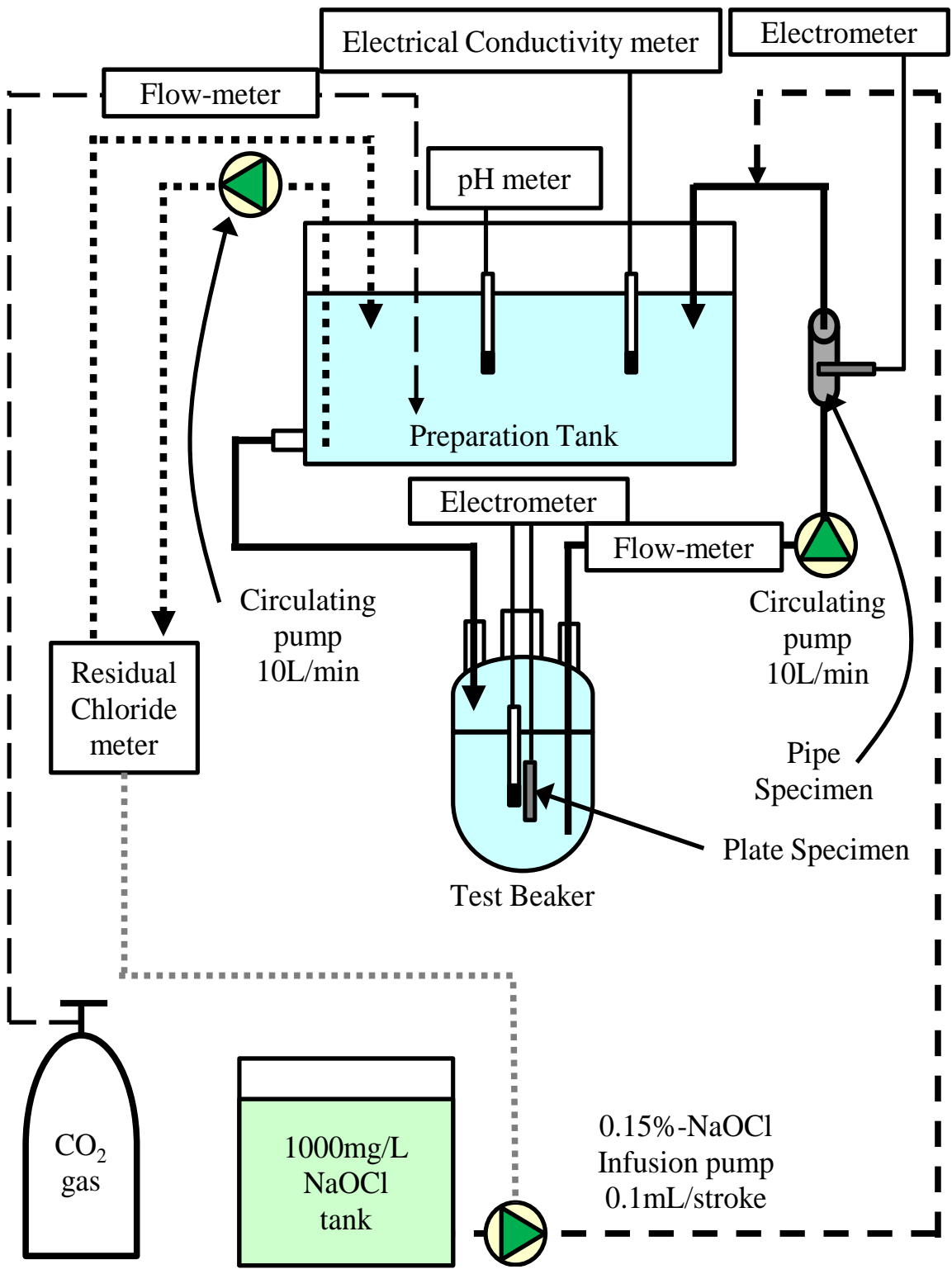

Figure 2. Schematic drawing of circulating corrosion test equipment.

days with the upper limit of $30 \mathrm{mS} / \mathrm{m}$ while monitoring the electric conductivity of the preparation tank. It supplied test water to a residual chlorine concentration control unit and controlled a chemicals feed pump to become the predetermined concentration while monitoring concentration. $\mathrm{pH}$ supplied carbon dioxide gas with constant flow quantity and stabilized it in $7.2 \pm 0.1$. The test performed the test water temperature degree at room temperature during 30 days. The test materials after test observed the corrosion condition by energy dispersive X-ray spectrometer (write it down with EDX.), digital microscope and a scanning electron microscope (write it down with SEM). The test water performed the water quality analysis at the time of a test start and the end. During the test measured about residual chlorine concentration, $\mathrm{pH}$, electric conductivity, water temperature and immersion potential. 


\subsection{Result and Discussion}

\subsubsection{Inner Diameter and Corrosion Resistance}

Figure 3 shows a comparison of immersion potential between plate and straight pipe specimens for a residual chlorine concentration of $0 \mathrm{mg} / \mathrm{L}$ over a period of 5 days. The plate specimen is rose from $0.1 \mathrm{~V}$ vs. SCE at test start time to $0.15 \mathrm{~V}$ vs. SCE at $1 / 3$ days and changed in $0.2 \mathrm{~V}$ vs. SCE at 5 days. In contrast, the straight pipe specimen is descended from $0.5 \mathrm{~V}$ vs. SCE at test start time to 0.32 $\mathrm{V}$ vs. SCE at $1 / 3$ day and remained as it was equivalent until5days. The result showed a conflicting tendency which the plate specimen is rose and the straight pipe specimen is descend.

Super microhardness measurements of plate and straight pipe specimens 13 $\mathrm{mm}, 25 \mathrm{~mm}$, and $50 \mathrm{~mm}$ in inner diameter were performed to investigate the influence of processing on the immersion potential. Figure 4 shows a comparison of Vickers hardness equivalent between plate and straight pipe specimens. It was shown with 281 at $13 \mathrm{~mm}, 265$ at $25 \mathrm{~mm}$ and 251 at $50 \mathrm{~mm}$ of the straight pipe specimen in comparison with a plate specimen being 245 generally that a direct pipe was harder. Straight pipe is produced by bending the raw materials of plate, and this bending is expected to affect the surface [21] [22]. As a firm tendency was seen so that the inner diameter was small, it was thought that there was much processing deformation-induced martensite production so that the inner diameter was small [21] [22]. It was thought that the final test result came under this influence, and a difference occurred for the immersion potential behavior. It is thought that corrosion behavior varies according to this influence with a plate specimen and the straight pipe specimen.

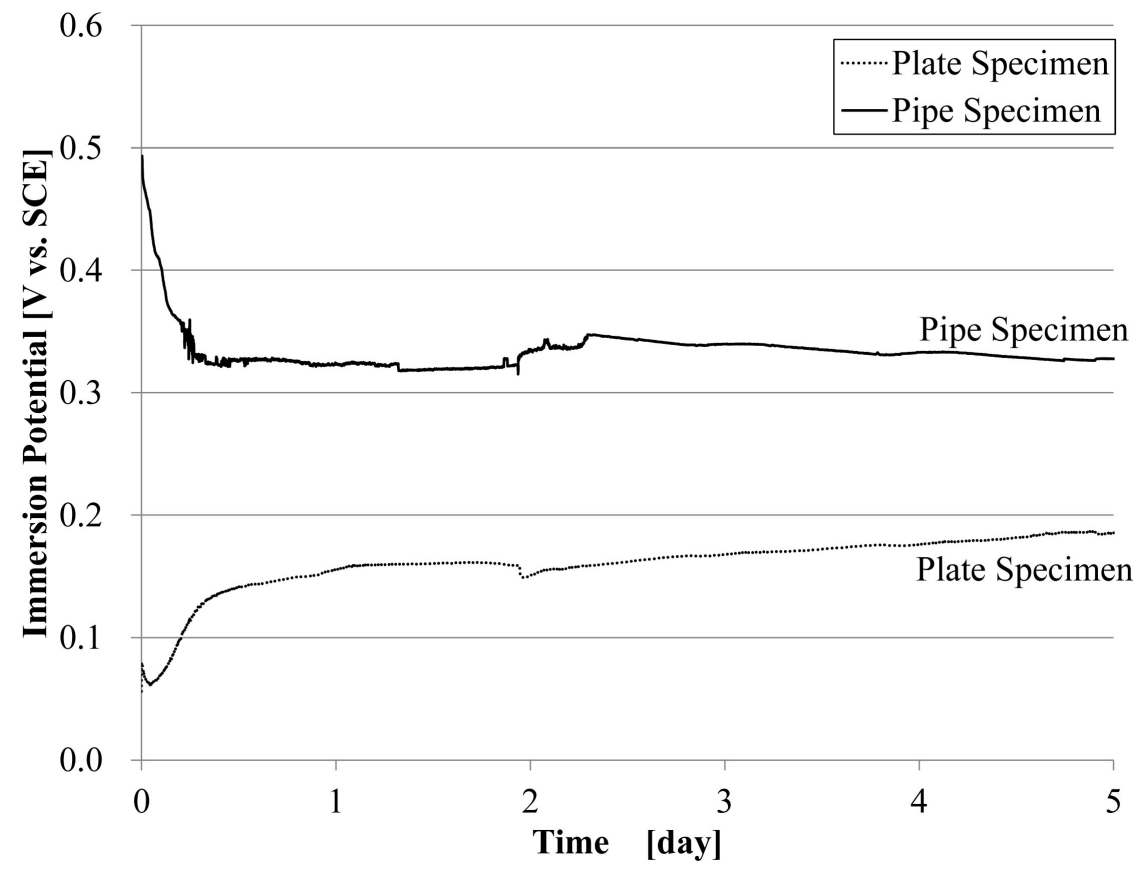

Figure 3. Comparison of immersion potential between plate specimen and pipe specimen in the case $0 \mathrm{mg} / \mathrm{L}$ of residual chlorine concentration. 


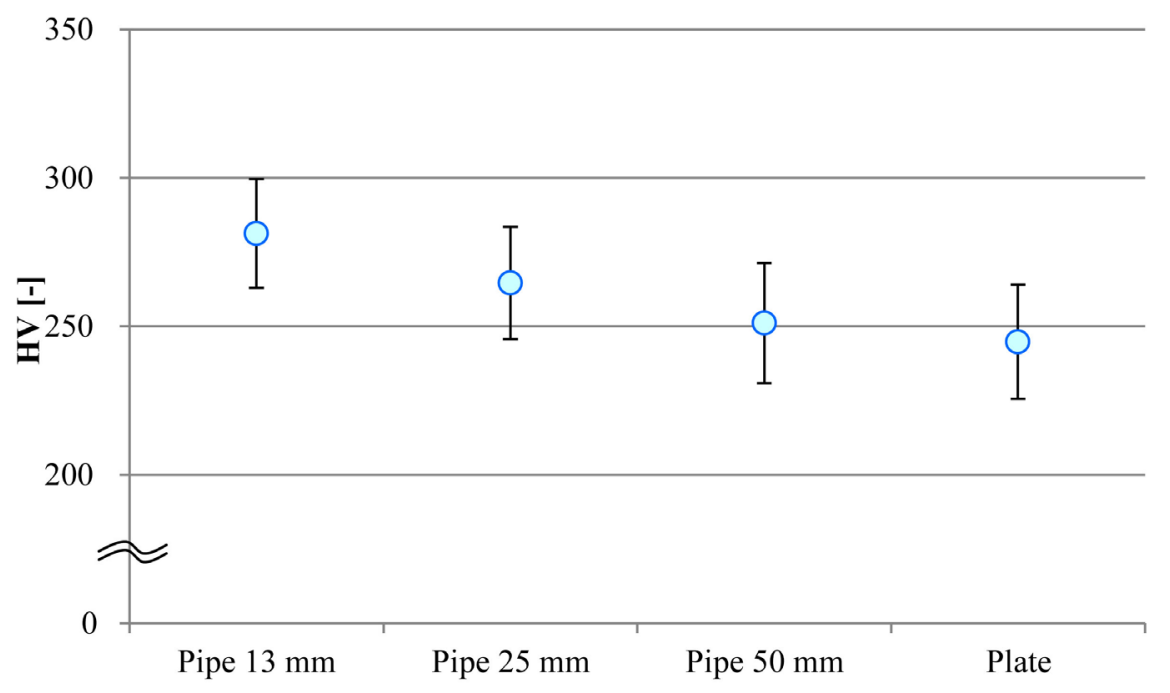

Figure 4. Comparison of vickers hardness between plate specimen and pipe specimen.

\subsubsection{Residual Chlorine Concentration and Corrosion Resistance}

Figure 5 shows the changes in immersion potential of (a) plate specimens and (b) straight pipe specimens at different residual chloride concentrations to 5 days pass. The immersion potential of straight pipe specimens was $0.5 \mathrm{~V}$ vs. SCE at the start of the test for all residual chloride concentrations examined. The value for the straight pipe specimen decreased by $1 / 3$ days from $0.5 \mathrm{~V}$ vs. SCE to $0.32 \mathrm{~V}$ vs. SCE at $0.0 \mathrm{mg} / \mathrm{L}, 0.2 \mathrm{~V}$ vs. SCE at $0.3 \mathrm{mg} / \mathrm{L}, 0.25 \mathrm{~V}$ vs. SCE at $0.5 \mathrm{mg} / \mathrm{L}$ and $0.1 \mathrm{~V}$ vs. SCE at $1.0 \mathrm{mg} / \mathrm{L} .0 .3 \mathrm{mg} / \mathrm{L}$ decreased to $0.15 \mathrm{~V}$ vs. SCE by 1 day, then it rapidly rose to $0.25 \mathrm{~V}$ vs. SCE and remained as it was until 5 days. After 1 day overall the immersion potential was almost stable but $1.0 \mathrm{mg} / \mathrm{L}$ continued gently descent even after 5 days. The immersion potential after 5 days was $0.32 \mathrm{~V}$ vs. SCE at $0.0 \mathrm{mg} / \mathrm{L}, 0.2 \mathrm{~V}$ vs. SCE at 0.4 and $0.5 \mathrm{mg} / \mathrm{L}, 0.25 \mathrm{~V}$ vs. SCE at 0.3 and $0.1 \mathrm{~V}$ vs. SCE at $1.0 \mathrm{mg} / \mathrm{L}$. The immersion potential with residual chlorine concentration of $0.3 \mathrm{mg} / \mathrm{L}$ or more showed a behavior to descend after starting as similar to $0.0 \mathrm{mg} / \mathrm{L}$. A dependent tendency of the residual chlorine concentration was seen in the straight pipe specimen conspicuously. However, 0.3, 0.4, 0.5 and $1.0 \mathrm{mg} / \mathrm{L}$ of plate specimen showed conflicting behavior of immersion potential on the plate specimen. The immersion potential sharply increased from $0.1 \mathrm{~V}$ vs. SCE at the start of the test to $0.3-0.4 \mathrm{~V}$ vs. SCE at $1 / 12$ days and then continued to gently increase until 5 days. $0.3 \mathrm{mg} / \mathrm{L}$ rapidly decreased from 0.4 to 0.3 at 1 day and then continued to gently rise. On the other hand, the immersion potential of $0.0 \mathrm{mg} / \mathrm{L}$ remained at $0.2 \mathrm{~V}$ vs. SCE of the thing which showed similar behavior. At all residual chlorine concentrations, the straight pipe specimens and plate specimens showed conflicting immersion potential behaviors. Figure 6 shows a comparison of the maximum immersion potential value as a function of residual chlorine concentration between the results of the present study and those reported previously [25] [26]. Since the sign of corrosion observed to test materials after the test is thought that reached the destruction of passive state film, plotted a maximum value of the immersion potential. The result evaluated 


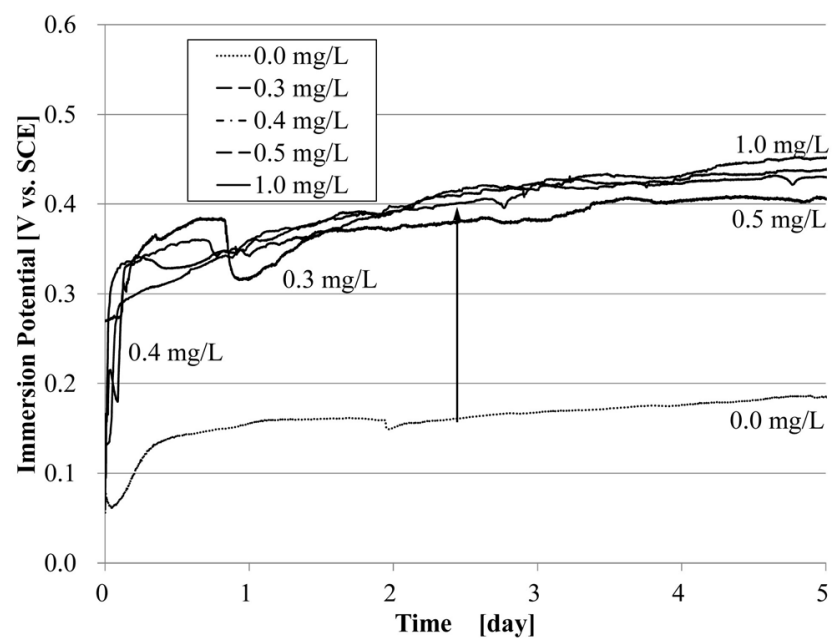

(a)

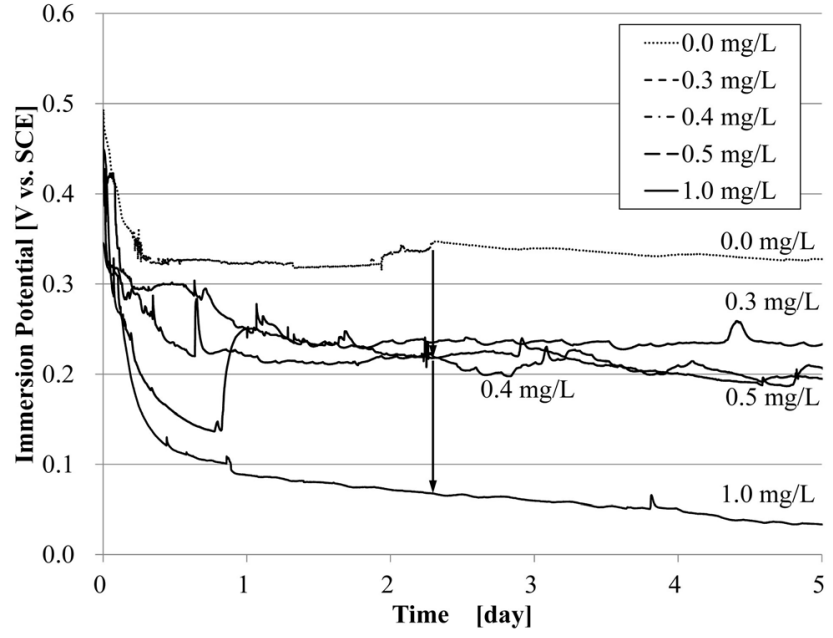

(b)

Figure 5. Changes in immersion potential of (a) Plate specimens and (b) Pipe specimens in different residual chlorine concentration.

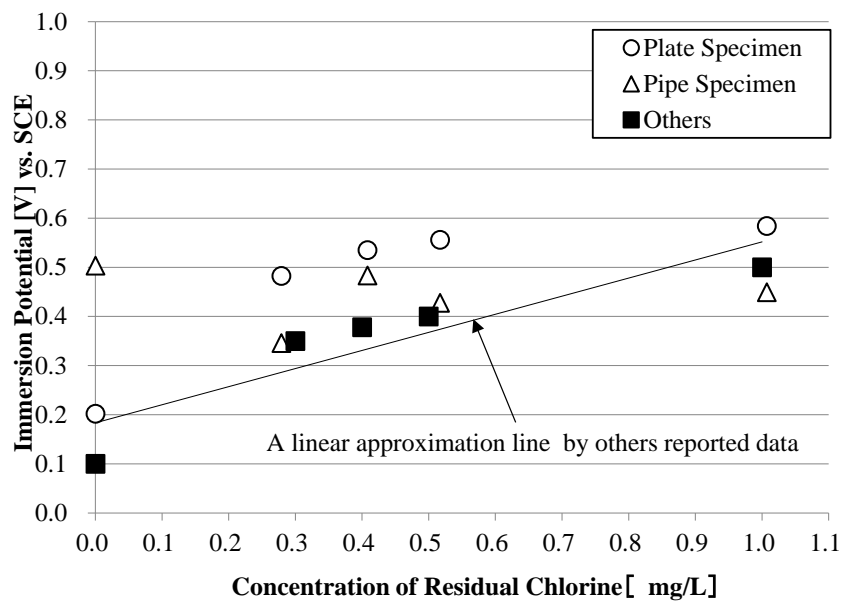

Figure 6. Maximum value of immersion potential as a function of residual chlorine concentration. For comparison, others reported results are also shown in this figure. 
made based on the approximation straight line created using the others report data. Good agreement of the maximum immersion potential of straight pipe specimens was seen between this study and previous reports for all residual chlorine concentration conditions except $0.0 \mathrm{mg} / \mathrm{L}$. In addition, it is thought that as a result, the pitting corrosion potential of stainless steel type 304 is to around $0.4 \mathrm{~V}$ vs. SCE more. About the plate specimen, the tendency that it was $0.1 \mathrm{~V}$ vs. SCE higher in than the others report was seen in $0.3,0.4$, and $0.5 \mathrm{mg} / \mathrm{L}$. However, good agreement was seen at 0.0 and $1.0 \mathrm{mg} / \mathrm{L}$.

Table 4 presents a summary of the test results. Changes in color indicating corrosion were observed on the surfaces of the test materials under all condition except for plate specimen with a residual chlorine concentration of $0.0 \mathrm{mg} / \mathrm{L}$. Figure 7 shows examples of SEM and EDX analysis results regarding changes in color of the specimens. Changes in color to dark brown corresponding to iron rust were seen in the photographs obtained with the digital microscope shown in Figure $7(a)$ ). In addition, the trace that the accretion of thought to be the corrosion product was exfoliated at the center of the changedin color department, it was seen than a SEM photograph to show in Figure 7(b). The area surrounded by a square in Figure 7 (c) indicates the region subjected to EDX analysis. The Cr that $18 \%-20 \%$ of content was standards decreased to $2.95 \%$ than EDX analysis for analysis point (1) to show in Figure 7(d) and was suggested with the corrosion product of iron oxide consisting than content of $\mathrm{Fe}$ and $\mathrm{O}$. As $\mathrm{Cl}$ was included in this corrosion product, corrosion influence with the $\mathrm{Cl}$ was thought about. O was undetected even though $\mathrm{Cr} 21.25 \%$, Fe $70.39 \%$, Ni $6.28 \%$ were detected in one analysis point (2). As an extreme difference was seen in content of $\mathrm{Cr}$ and $\mathrm{O}$ in analysis point (1) and (2), it is thought that a surface state changes by progress of the corrosion. The passive state film is destroyed under the influence

Table 4. Inner surface condition and immersion potential of specimens for residual chlorine concentration.

\begin{tabular}{|c|c|c|c|c|c|}
\hline & \multirow{2}{*}{ R-Cl ${ }_{2}$ conc. $[\mathrm{mg} / \mathrm{L}]$} & \multirow{2}{*}{ Pitting } & \multicolumn{3}{|c|}{ Immersion Potential [V vs. SCE] } \\
\hline & & & 0 [day] & 2 [day] & Difference \\
\hline \multirow{5}{*}{ Plate } & 0.0 & No & 0.08 & 0.16 & 0.08 \\
\hline & 0.3 & Occurred & 0.27 & 0.38 & 0.11 \\
\hline & 0.4 & Occurred & 0.10 & 0.40 & 0.30 \\
\hline & 0.5 & Occurred & 0.13 & 0.39 & 0.26 \\
\hline & 1.0 & Occurred & 0.13 & 0.40 & 0.27 \\
\hline \multirow{5}{*}{ Pipe } & 0.0 & Occurred & 0.48 & 0.34 & -0.14 \\
\hline & 0.3 & Occurred & 0.35 & 0.23 & -0.12 \\
\hline & 0.4 & Occurred & 0.46 & 0.22 & -0.24 \\
\hline & 0.5 & Occurred & 0.42 & 0.22 & -0.20 \\
\hline & 1.0 & Occurred & 0.45 & 0.07 & -0.38 \\
\hline
\end{tabular}

$\mathrm{R}-\mathrm{Cl}_{2}$ : Residual Chlorine. 


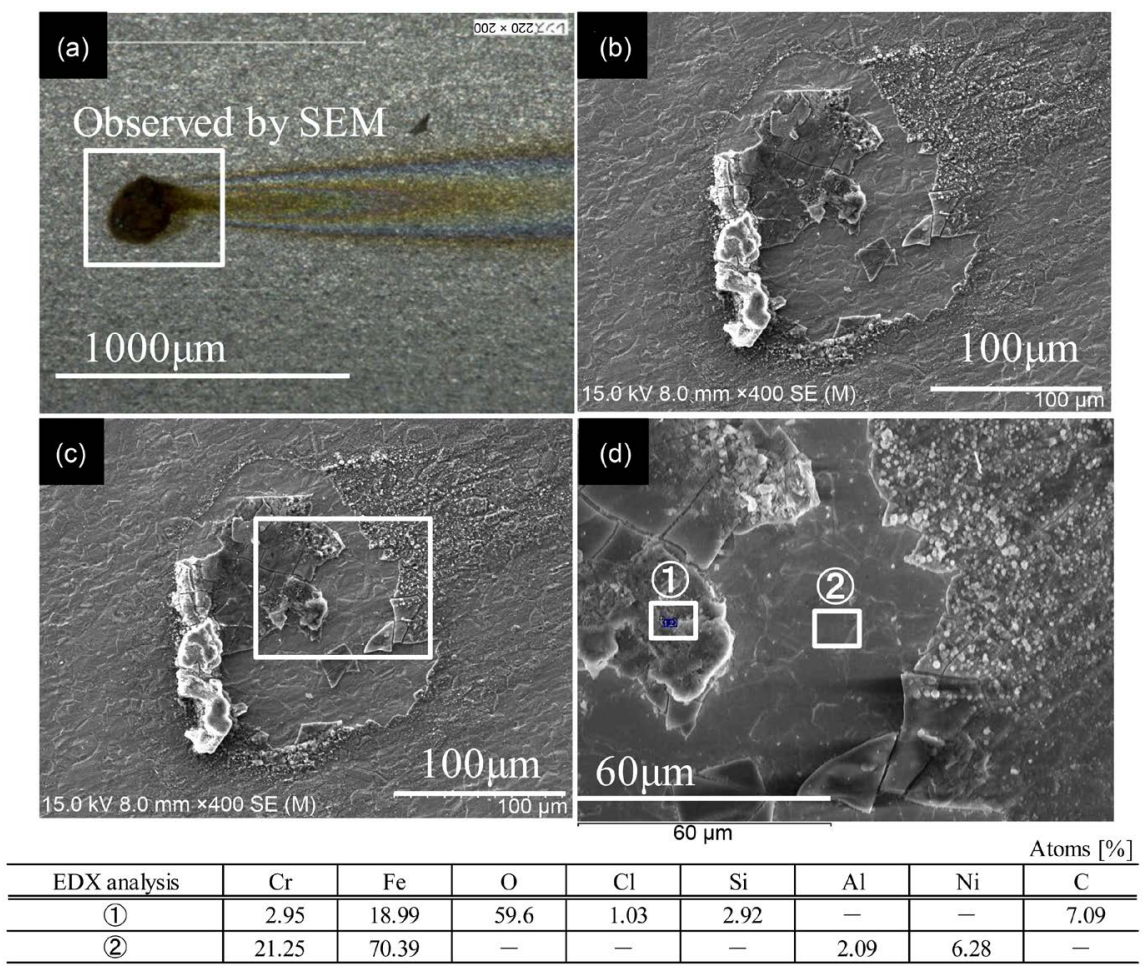

Figure 7. Picture of (a) digital microscopic observation; (b) SEM analysis; (c) and (d) EDX analysis for pipe specimen in $1.0 \mathrm{mg} / \mathrm{L}$ of residual chlorine concentration. For comparison, the content ratio of elements by EDX analysis are shown in this figure.

of $\mathrm{Cl}$ than these SEM observation and EDX analysis in the change of color department, and corrosion progresses, and it is thought that the corrosion product mainly composed of iron oxide deposits. As a change of color department was extremely local, I did not come to evaluate the progress of the pitting corrosion by the section observation definitely. However, it is thought that this change of color department becomes the starting point of the pitting corrosion than the existence of the corrosion product.

On the other hand, the immersion potential showed behavior to disagree with like $0.0 \mathrm{mg} / \mathrm{L}$ in residual chlorine concentration $0.3 \mathrm{mg} / \mathrm{L}, 0.4 \mathrm{mg} / \mathrm{L}, 0.5 \mathrm{mg} / \mathrm{L}$, and $1.0 \mathrm{mg} / \mathrm{L}$ with a plate specimen and the straight pipe specimen. In addition, immersion potential of a plate specimen and the straight pipe specimen behavior disagreed, but was admitted dependence of the residual chlorine concentration by a time change.

Since the pitting corrosion potential of stainless steel type 304 has been considered to be around $0.4 \mathrm{~V}$ vs. SCE in this study, electrochemical inspection is now carried out by the polarization method and constant potential method, and a detailed investigation of corrosion form is underway.

\section{Conclusions}

This study was performed to examine the corrosion of stainless steel type 304 pipes used in water supply and hot water supply facilities. The results can be 
summarized as follows.

1) There was more corrosion of pipe parts $<50 \mathrm{~mm}$ in inner diameter used for hot water supply facilities with residual chlorine concentration less than 0.4 $\mathrm{mg} / \mathrm{L}$ as use environment than a case investigation.

2) The changes in immersion potential of plate and straight pipe specimens over time were dependent on residual chlorine concentration. The residual chlorine concentration dependence was remarkable in the straight pipe specimen, and the higher the residual chlorine concentration was, the larger the drop width of the immersion potential was.

3) In a corrosion test, changes of color departments thought to be a sign of the corrosion in all test conditions to remove $0.0 \mathrm{mg} / \mathrm{L}$ of the plate specimen were observed. It was thought that a change of color department became the starting point of the pitting corrosion than SEM observation and EDX analysis.

4) As the straight pipe specimens were harder than the plate specimens, corrosion sensitivity appeared to increase with deformation-induced martensite production.

5) As a tendency to be tense so that the inner diameter became small was seen in the straight pipe specimen, production of deformation-induced martensite increased so that the inner diameter became small, and it was thought that corrosion sensitivity became higher.

\section{References}

[1] Tsujikawa, S., Ishihara, Y. and Shinohara, T. (1993) Failure Analysis of Stress Corrosion Cracking of Type 304 Steel Tubing for Hot-Water Use in Kusatsu Town, Gunma Prefecture. Zairyo-to-Kankyo, 42, 20-26. https://doi.org/10.3323/jcorr1991.42.20

[2] Azuma, S., Miyuki, H., Murayama, J. and Kudo, T. (1990) Effect of Weld Scale on Corrosion Resistance of Stainless Steels. Corrosion Engineering, 39, 603-609. https://doi.org/10.3323/jcorr1974.39.11_603

[3] Miura, M. and Ogawa, K. (1988) Welding Stainless with High Corrosion Resistance. Journal of the Japan Welding Society, 57, 421-426. https://doi.org/10.2207/qjjws1943.57.421

[4] Garner, A. (1982) Corrosion of High Alloy Austenitic Stainless Steel Weldings in Oxidizing Environments. Mater Perform, 21, 9-14.

[5] Yamamoto, K. (1984) Application of Low Interstitial Ferritic Stainless Steels like Type 444 Steel in Chemical Plants. Corrosion Engineering, 33, 587-594. https://doi.org/10.3323/jcorr1974.33.10_587

[6] Lundqvist, B., Norberg, P. and Olsson, K. (1986) Influence of Different Welding Conditions on Mechanical Properties and Corrosion Resistance of SAF 2205 (UNS S31803). Proceeding in Duplex Stainless Steel'86, The Hague, 16.

[7] Fukuda, T. and Shimazaki, M. (1986) Proceeding in Duplex Stainless Steel'86, 363.

[8] Kearns, J.R. (1985) The Corrosion of Heat Tinted Austenaitic Stainless Alloys. CORROSION'85, Boston, 50.

[9] Wilson, R.K. and Anderson, D.B. (1983) Effects of Microstructure on the Corrosion Resistance of Welded High Alloy Stainless Steel. CORROSION'83, Houston, 193. 
[10] Azuma, S., Kushida, T. and Kudo, T. (1990) CORROSION'90, Las Vegas, 69.

[11] Nakajima, N. (2005) Local Corrosion Case of Hot Water Supply Pipe. Proceedings of JSCE Materials and Environments 2005, Tokyo, A-115.

[12] Yamate, T. (2008) Corrosion Cases and Countermeasures of Stainless Steel Piping for Buliding Equipment. Proceedings of JSCE Materials and Environments 2008, Tokyo, D-306.

[13] Hosoya, K., Takada, K. and Nakamura, S. (2008) Corrosion Case of Stainless Steel Pipe in Hot Water Supply. Proceedings of JSCE Materials and Environments 2008, Tokyo, D-307.

[14] Takada, K., Ogura, T. and Hosoya, K. (2012) Water Quality Examination of Corrosion Cases of Stainless Steel. Proceedings of JSCE Materials and Environments 2012, Tokyo, C-308.

[15] Adachi, T. (1994) Effects of P and Cu on SCC Resistance of Austenitic Stainless Steel in Dilute $\mathrm{NaCl}$ Solution. Zairyo-To-Kankyo, 43, 126-133. https://doi.org/10.3323/jcorr1991.43.126

[16] DAI-DAN Co., Ltd. (2001-2015) Company Example.

[17] Randak, A. and Trautes, F.W. (1970) Werks. u. Korr. 97.

[18] Maekawa, T., Kagawa, M. and Nakajima, N. (1963) Effect of Cold Working on Stress-Corrosion of Stainless Steels. Journal of the Japan Institute of Metals and Materials, 27, 548-553. https://doi.org/10.2320/jinstmet1952.27.11_548

[19] Maekawa, T., Nakajima, N. and Kagawa, M. (1965) Effect of Cold-Working on Anodic Polarization of Austenitic Stainless Steels in the Sulfuric Acid Solution. Journal of the Japan Institute of Metals and Materials, 29, 248-252. https://doi.org/10.2320/jinstmet1952.29.3_248

[20] Ueda, H. and Sugawara, H. (1977) Role of Strain Induced Martensite on Stress Corrosion Cracking of 18-8 Stainless Steel in $\mathrm{H}_{2} \mathrm{SO}_{4}-\mathrm{NaCl}$ Solution. Journal of Japan Institute of Metals and Materials, 41, 528-534. https://doi.org/10.2320/jinstmet1952.41.5_528

[21] Sunada, S., Maesato, H., Yokoi, Y., Notoya, H., Sanuki, S. and Arai, K. (1990) Effect of Deformation-Induced Martensite on Pitting Corrosion of SUS304 Stainless Steel in $\mathrm{H}_{2} \mathrm{SO}_{4}-\mathrm{NaCl}$ Solution. Journal of Japan Institute of Metals and Materials, 54, 1078-1086. https://doi.org/10.2320/jinstmet1952.54.10_1078

[22] Fujii, M. and Kumada, M. (1970) Pitting Dissolution Behavior in the Cold-Worked $18 \mathrm{Cr}-8 \mathrm{Ni}$ Stainless Steel. Journal of Japan Institute of Metals and Materials, 34, 1001-1004. https://doi.org/10.2320/jinstmet1952.34.10_1001

[23] Fujii, M. and Kumada, M. (1970) Effect of the Oxide Film on the Pitting Corrosion in $18 \mathrm{Cr}-8 \mathrm{Ni}$ Stainless Steel. Journal of Japan Institute of Metals and Materials, 34, 1005-1011. https://doi.org/10.2320/jinstmet1952.34.10_1005

[24] Grassiani, M. (1978) Israel Journal of Technology, 16, 169.

[25] Watanabe, T. and Komukai, S. (1997) Effect of Residual Chlorine on Corrosion Resistance of Austenitic Stainless Steel Tube Weldments in Hot Water. Zairyo-toKankyo, 46, 783-788. https://doi.org/10.3323/jcorr1991.46.783

[26] Nishikawa, M., Harada, W., Adachi, T. and Nagoya, T. (1998) Corrosion Resistance of Stainless Steel Piping for Water and Hot-Water Supply. Nisshin Steel Technical Report, 77, 25-40. 